\title{
PENCEGAHAN TINDAKAN PELECEHAN SEKSUAL REMAJA MELALUI LAYANAN INFORMASI DALAM PELAKSANAAN BIMBINGAN DAN KONSELING DI SEKOLAH
}

\author{
Oleh : Firman dan Sahniar Jurusan Bimbingan dan Konseling Fakultas Ilmu Pendidikan \\ Universitas Negeri Padang
}

\author{
Email : firman@konselor.org
}

\begin{abstract}
Abstrak
Layanan informasi dalam kegiatan bimbingan dan konseling di sekolah selama ini belum termanfaatkan secara maksimal untuk pencegahan tindakan pelecehan seksual remaja yang berasal dari Sekolah Menengah Atas (SMA). Penelitian ini ditujukan merumuskan panduan layanan informasi untuk pencegahan tindakan pelecehan seksual remaja yang berasal dari Sekolah Menengah Atas (SMA). Penelitian ini menggunakan Research and Development (R\&D) model 4-D, dengan penggumpulan data melalui kuessioner, wawancara dan observasi serta analisis dokumen. Data dianalisis secara naratif dan deskriptif. Berdasarkan hasil penelitian ditemukan sebanyak 49,61\% siswa Sekolah Menengah Atas (SMA) memiliki kecenderungan melakukan tindakan pelecehan seksual, mulai dari intensitas sedang, tinggi dan sangat tinggi. Sebagian besar pelecehan seksual yang dilakukan remaja berasal dari SMA bersifat verbal dan visual. Layanan informasi yang diperlukan remaja berasald ari SMA dirumuskan dari perencanaan, pelaksanaan, evaluasi dan tiondak lanjut. Topik pembahasan yang digunakan, menyangkut dengan : pelecehan seksual beserta akibatnya, aturan-aturan berkaitan dengan pelecehan seksual beserta dampak pelanggarannya, dan toleransi antar jenis kelamin dalam mengimplimentasikan aturan berkaitan dengan pelecehan seksual. Panduan layanan informasi untuk pencegahan kecenderungan tindakan pelecehan seksual remaja telah valid, efektif dan praktis digunakan dalam pelaksanaan bimbingan dan konseling melalui layanan inforamsi di sekolah.
\end{abstract}

Kata Kunci : Layanan informasi, contextual teaching and learning, dan pelecehan seksual

\section{A. Pendahuluan}

Dewasas ini kejahatan seksual dialami anak Indonesia semakin meningkat, yang ditunjukkan oleh pornografi, kekerasan dan eksplorasi seksual. Tahun 2011 ditemukan sebanyak 14,46 persen, tahun 2012 meningkat menjadi 22,6 persen, tahun 2013 sampai dengan bulan Oktober, ditemukan sebanyak 15,85 persen dari keseluruhan kasus dialami anak (Ratih Probosiwi, 2015).Korban kekerasan seksual sebagian besar dialami anak laki-laki sebanyak 60 persen dan 40 persen perempuan. Di sisi lain, Perserikatan Bangsa Bangsa (PBB) menemukan korban kekerasan seksual dialami anak perempuan lebih tinggi dari laki-laki (Ratih Probosiwi, 2015).

Pelaku kerjahatan seksual sebagian besarr dilakukan oleh anak yang sedang menjalani usia remaja..Havighurst (dalam Kusmiran, 2011) menjelaskan periode remaja mempunyai tugas-tugas perkembangan yang harus mereka capai agar bisa berkembang secara optimal. Salah satu tugas perkembangan yang harus dicapai yaitu menguasai kemampuan membina hubungan baru dan lebih matang dengan teman sebaya yang sama atau berbeda jenis kelamin. Blair dan Jones., Ramsey., Mead., Dusek., dan Besonky (dalam Mudjiran dkk., 2007) menjelaskan ciri khas perkembangan remaja salah satunya adalah remaja memiliki keterkaitan yang kuat dengan lawan jenisnya. 
Komnas Perempuan (2015) mengungkapkan klasifikasi kekerasan seksual berdasarkan hasil pemantauannya selama 15 tahun (1998- 2013), yaitu: (1) perkosaan, (2) intimidasi seksual termasuk ancaman atau percobaan perkosaan, (3) pelecehan seksual, (4) eksploitasi seksual, (5) perdagangan perempuan untuk tujuan seksual, (6) prostitusi paksa, (7) perbudakan seksual, (8) pemaksaan perkawinan, termasukcerai gantung, (9) pemaksaan kehamilan, (10) pemaksaan aborsi, (11) pemaksaan kontrasepsi dan sterilisasi, (12) penyiksaan seksual, (13) penghukuman tidak manusiawi dan bernuansa seksual, (14) praktik tradisi bernuansa seksual yang membahayakanatau mendiskriminasi perempuan, dan (15) kontrol seksual, termasuk

Supardi \& Sadarjoen (2006) menjelaskan pelecehan seksual merupakan salah satu bentuk tindakan kekerasan dialami anak. Pelecehan seksual adalah tindakan seseorang atau sejumlah orang yang tidak diinginkan serta berakibat negatif oleh individu jadi sasaran tindakan tersebut. Jim Burn (2015) menjelaskan pelecehan seksual terhadap anak terjadi dalam banyak bentuk yang membuat ketidak nyaman atas paksaan, penipuan ataupun ancaman melakukan kontak seksual dengannya.

Pelecehan seksual di kalangan remaja mengalami peningkatan, Berdasarkan data Komisi perlindungan Anak Indonesia (KPAI) menemukan tahun 2014 terdapat 30 kasus anak menjadi korban pelecehan seksual, tahun 2015 terdapat 37 kasus , tahun 2016 terdapat 51 kasus. Yulita Amaliyasari (2008) menjelaskan faktor internal mempengaruhi perilaku seksual berkaitan dengan jenis kelamin, pengetahuan tentang seks dan kesehatan reproduksi, serta motivasi seksual. Fuadi (2011) menjelaskan remaja yang tidak mempunyai pengetahuan tentang perilaku seksual menjadi salah satu penyebab terjadinya pelecehan seksual. Green beerg (Prapto, 2008) menjelaskan apabila diklasifikasikan remaja mendapatkan informasi mengenai seks $21 \%$ diperoleh dari rumah, $15 \%$ dari sekolah, $28 \%$ dari media seperti internet, majalah dan film dan $40 \%$ dari teman sebaya.

Berbagai kegiatan bimbingan dan konseling dilalui siswa di sekolah untuk peningkatan pemahaman tentang diri dan lingkungannya. Salah satu jenis layanan bimbingan dan konseling yang diberikan di sekolah yaitu layanan informasi. Sari (2016) menjelaskan guru BK/konselor mempunyai tanggungjawab untuk mencegah remaja dari pelecehan seksual, remaja bisa menjadi korban ataupun menjadi pelaku pelecehan seksual. Salah satu cara mencegah pelecehan seksual itu terjadi adalah memberikan siswa pemahaman dan pengetahuan tentang sikap positif seksualitas melalui layanan informasi.

Penyelenggaraan layanan informasi dapat dilakukan dengan berbagai strategi yang berpusat kepada peserta didik maupun Guru BK/Konselor Sekolah. Layanan informasi bersifat konvensional berorientasi pemberian informasi satu arah bersumber dari Guru BK/Konselor Sekolah. Selain dari informasi, siswa membutuhkan teladan yang memungkinkan mereka belajar mengenal berbagai hal melalui proses dengan strategi moderen berpusat kepada peserta didik (Sari, 2015).

Strategi pembelajaran Contextual Teaching Learning dapat diadaptasi dalam pelaksanaan layanan informasi untuk menyelesaikan permasalahan kekurangan informasi remaja siswa Sekolah Menengah Atas (SMA) tentang pelecehan seksual beserta akibat yang menyertainya. Rusman (2010) menjelaskan model pembelajaran kontekstual merupakan model pembelajaran yang memfasilitasi kegiatan belajar untuk mencari, mengolah, dan menemukan pengalaman belajar yang bersifat konkrit melalui keterlibatan aktifitas siswa dalam mencoba, melakukan dan mengalami sendiri..

Pendekatan Contextual Teaching and Learning (CTL) jika dibandingkan dengan pendekatan konvensional lebih banyak keunggulan. Pendekatan Contextual Teaching and Learning merupakan salah satu pendekatan yang mampu menghidupkan kelas agar siswa memperoleh informasi dengan sesungguhnya. Taufik dan Muhammadi, (2012:189) menjelaskan pendekatan kontekstual merupakan suatu model pembelajaran dimana guru menghadirkan situsasi dunia nyata ke dalam kelas dan mendorong peserta didik membuat hubungan antara pengetahuan yang dimilikinya dengan penerapannya dalam kehidupan mereka. Pendekatan kontekstual dapat mengaitkan pengetahuan yang dimiliki oleh peserta didik dengan situasi dunia nyata. 
Berdasarkan uraia tersebut, menarik diungkap lebih lanjut melalui tulisan ini bagaimana efektifitas pengembangan panduan layanan informasi menggunakan kontextual teaching and learning dalam pencegahan tindakan pelecehan seksual remaja di sekolah. Pengungkapan permasalahan tersebut bermanfaat dalam pencegahan tindakan pelecehan seksual melalui layanan inforamsi dalam pelaksanaan bimbingan dan konseling di sekolah

B. Metode Penelitian

Penelitian ini menggunakan Research and Development), dengan model 4-D, yang dikemukakan oleh S. Thiagarajan, Dorothy S. Semmel, dan Melvyn I. Semmel. Thiagarajan, dkk. (dalam Trianto, 2012:189), dengan tahap sebagai berikut: (1) tahap pendefenisian (define), (2) Tahap perancangan (design), (3) Tahap pengembangan (develop), (4) Tahap penyebaran (disseminate). Populasi penelitian siswa dan Guru BK/Konselor Sekolah Sekolah Menengah Atas (SMA) Negeri dan Swasta Kota Padang. Pengambilan sampel menggunakan teknik cluster random sampling dan pusposive. Pengumpulan data menggunakan kuessioner, observasi, wawancana dan analisis dokumen.

C. Hasil dan Pembahasan

Kecenderungan Tindakan Pelecehan Seksual Remaja

Kecenderungan tindakan pelecehan seksual remaja yang diungkapkan melalui penelitian ini menyangkut dengan tingkah laku individu secara verbal, visual dan fisik melanggar nilai kesopanan berkaitan dengan seksual sehingga menimbulkan perasaan yang ketidak nyaman, marah, malu, terintimidasi, dan menyinggung orang lain. Berdasarkan hasil penelitian ditemukan kencerungan tindakan pelecehan seksual remaja Siswa Sekolah Menengah Atas (SMA) terlihat pada tabel berikut :

Tabel. 1

Intensitas Kecenderungan Tindakan Pelecehan Seksual Remaja Siswa Sekolah Menengah Atas

\begin{tabular}{|c|l|c|c|c|c|c|c|c|c|c|c|}
\hline \multirow{2}{*}{ No. } & \multirow{2}{*}{ Indikator } & \multicolumn{10}{|c|}{ Intensitas } \\
\cline { 3 - 12 } & & ST & $\mathbf{\%}$ & $\mathbf{T}$ & $\mathbf{\%}$ & S & $\mathbf{\%}$ & $\mathbf{R}$ & $\mathbf{\%}$ & SR & \% \\
\hline 1 & Verbal & 63 & 25 & 49 & 19,44 & 56 & 22,22 & 41 & 16,27 & 43 & 17,06 \\
\hline 2 & Visual & 59 & 23,41 & 46 & 18,25 & 53 & 21,03 & 57 & 22,62 & 37 & 14,68 \\
\hline 3 & Fisik & 8 & 3,17 & 28 & 11,11 & 77 & 30,55 & 87 & 34,52 & 52 & 20,63 \\
\hline \multicolumn{2}{|c|}{ Jumlah } & $\mathbf{1 1}$ & $\mathbf{4 , 3 6}$ & $\mathbf{2 7}$ & $\mathbf{1 0 , 7 1}$ & $\mathbf{3 1}$ & $\mathbf{1 2 , 3 0}$ & $\mathbf{5 6}$ & $\mathbf{2 2 , 2 2}$ & $\mathbf{1 2 7}$ & $\mathbf{5 0 , 3 9}$ \\
\hline
\end{tabular}

Berdasarkan tabel di atas, terlihat sebanyak 50,39 \% remaja siswa sekolah menengah atas memiliki kecenderungan tindakan pelecehan seksual sangat rendah. Selanjutnya sebanyak $22,22 \%$ rendah, $12,30 \%$ sedang, 10,71 \% tinggi dan 4,36 \% sangat tinggi. Apabila dikalkulasikan sebanyak 39,41\% (12,30 sedang, 10,71 tinggi dan 4,36 sangat tinggi) telah memiliki kecenderungan tindakan pelecehan seksual terhadap orang lain. Dengan demikian dapat disimpulkan siswa sekolah menengah atas telah memiliki kecenderungan melakukan tindakan pelecehan seksual sebanyak sebanyak $27,37 \%$.

Berdasarkan tabel di atas juga menjelaskan, remaja siswa SMA telah memiliki kecenderungan tindakan pelecehan seksual remaja siswa SMA bersifat verbal sebanyak 66,66 \% (25\% sangat tinggi, $19,44 \%$ tinggi, $22,22 \%$ Sedang) Selanjutnya tindakan pelecehan seksual yang dimiliki remaja siswa SMA bersifat visual sebanyak 62,69\% ( 23,41 \%, 18,25\% dan 21,03. Dengan demikian dapat disimpulkan memiliki kecenderung pelecehan seksual bersifal verbal dan visual.

Apabila ditelusuri lebih lanjut, ditemukan kecenderungan tindakan pelecehan seksual siswa berasal dari sekolah menengah atas swasta dengan negeri terdapat perbedaan. Perbandingan kecenderungan tindakan pelecehan seksual remaja berasal dari Sekolah Menengah Atas Negeri dibandingkan dengan Swasta yang bersifa verbal ditemukan remaja siswa Sekolah Menengah Atas Negeri dan Swasta 
berbeda, ditunjukan oleh hasil analisis koefisien ditemukan t hitung sebesar 10,583 dengan koefisien P-value sebesar 0,000 lebih kecil dari 0,05 maka dinyatakan terdapat perbedaan yang signifikan antara kencederungan tindakan pelecehan seksual yang bersifat verbal remaja Sekolah Menengah Atas Swasta dengan Sekolah Menengah Atas Negeri. Selanjutnya berdasarkan analisis koefisien kecenderungan pelecehan seksual dalam bentuk visual, diperoleh keterangan thitung sebesar 7,473 dengan koefisien P-value sebesar 0, SMA N Padang 000 lebih kecil dari 0,05 maka dinyatakan bahwa terdapat perbedaan yang signifikan antara pelecehan seksual siswa sekolah swasta dengan siswa sekolah menengah negeri. Berdasarkan analisis koefisien pelecehan seksual dalam bentuk fisik, $t$ hitung sebesar 8,814 dengan koefisien P-value sebesar 0,000 lebih kecil dari 0,05 maka dinyatakan bahwa terdapat perbedaan yang signifikan antara pelecehan seksual siswa dalam bentuk fisik pada SMA Baiturrahmah dan SMA N 2 Padang.

Panduan layanan informasi untukpencegahan kecenderungan tindakan pelecehan seksual Remaja

Penyusunan panduan layanan informasi didasarkan oleh data kecenderungan tindakan pelecehan seksual remaja sebanyak 49,61 \% melakukan tindakan pelecehan seksual, mulai dari intensitas sedang, tinggi dan sangat tinggi. Berdasarkan data tersebut dilakukan studi leteratur untuk merumuskan fokus kajian untuk merumuskan panduan layanan inforamasi untuk pencegahan pelecehan seksual, menyangkut dengan tingkah laku individu melawan nilai kesopanan berkaitan dengan seksual menyangkut dengan verbal, visual dan fisik yang menimbulkan perasaan yang tidak nyaman, marah, malu, terintimidasi, dan menyinggung orang lain. Topik pembahasan yang akan dibahas dalam layanan informasih, menyangkut dengan: pelecehan seksual beserta akibatnya, aturanaturan berkaitan dengan pelecehan seksual beserta dampak pelanggarannya, dan toleransi antar jenis kelamin dalam mengimplimentasikan aturan berkaitan dengan pelecehan seksual, Berdasarkan fokus dan topik yang akan dibahas dari layanan informasi, selanjutnya dilakukan perencanaan layanan informasi yang dimulai dari mengidentifikasi ruang lingkup tindakan pelecehanan seksual, indikator, topik dan permasalahan yang yang akan dibahas. Gambaran topik permasalahan sehubungan dengan kecenderungan pelecehan seksual remaja, terlihat pada tabel berikut :

Tabel.3

Ruanglingkup Topik Layanan informasi Menggunakan contextual teaching and learning dalam Pencegahan Kecenderungan Pelecehan dalam

\begin{tabular}{|c|l|l|l|}
\hline No & \multicolumn{1}{|c|}{$\begin{array}{l}\text { Ruanglingkup Kecerungan } \\
\text { Pelecehan Seksual }\end{array}$} & Indikator & $\begin{array}{l}\text { Topik } \\
\text { Pengembangan }\end{array}$ \\
\hline 1. & $\begin{array}{l}\text { Pelecehan seksual adalah } \\
\text { tingkah laku individu } \\
\text { menyangkut verbal, visual dan } \\
\text { fisik berkaitan dengan seksual } \\
\text { yang menimbulkan perasaan } \\
\text { yang tidak nyaman, marah, } \\
\text { malu, terintimidasi, dan } \\
\text { menyinggung orang lain. }\end{array}$ & $\begin{array}{l}\text { Kemampuan } \\
\text { mengenal } \\
\text { pelecehan seksual } \\
\text { yang menyertainya }\end{array}$ & $\begin{array}{l}\text { Pelecehan seksual } \\
\text { beserta dampak } \\
\text { pelanggarannya.. }\end{array}$ \\
$\begin{array}{l}\text { Kemampuan } \\
\text { mengenali } \\
\text { pelanggaran aturan } \\
\text { pelecehan seksual } \\
\text { beserta akibatnya } \\
\text { bagi pelangar. }\end{array}$ & $\begin{array}{l}\text { Aturan tentang } \\
\text { pelecehan seksual } \\
\text { berserta akibatnya } \\
\text { bagi pelanggar. }\end{array}$ \\
$\begin{array}{l}\text { Kemampuan } \\
\text { bertoleransi sesama }\end{array}$ & $\begin{array}{l}\text { Kemampuan } \\
\text { bertoleransi dalam } \\
\text { mengimplimentasikan }\end{array}$ \\
\hline
\end{tabular}




\begin{tabular}{|l|l|l|l|}
\hline & $\begin{array}{l}\text { dan antar jenis } \\
\text { kelamin sesuai } \\
\text { dengan norma } \\
\text { dalam berinteraksi . }\end{array}$ & $\begin{array}{l}\text { aturan tentang } \\
\text { pelecehan seksual } \\
\text { antar jenis kelamin. }\end{array}$ \\
\hline
\end{tabular}

Berdasarkan analisis dokumen, Kitab Undang-Udang Hukum Pidana (KUHP) ditemukan tidak mencantumkan istilah pelecehan seksual tetapi perbuatan cabul. Pasal 289 sampai dengan Pasal 296 KUHP menjelaskan istilah perbuatan cabul sebagai tindakan melanggar rasa kesusilaan, atau perbuatan lain yang keji, dan semuanya dalam lingkungan nafsu berahi kelamin. Sehubungan dengan hal itu, segala perbuatan yang melanggar kesopanan/kesusilaan, dapat dimasukkan sebagai perbuatan cabul. Apabila dikaitkan dengan tindakan pelecehan seksual yang dilakukan siswa Sekolah Menengah dapat dikategorikan sebagai tindakan pelanggaran anak. Kitab Undang-Undang Hukum Pidana (KUHP) dan Undang-Undang Perlindungan Anak No 23 Tahun 2002 menjelaskan tindak pidana pelecehan seksual terhadap anak di bawah umur merupakan sebuah kejahatan kesusilaan yang bagi pelakunya harus diberikan hukuman yang setimpal. Selanjutnya Undang -Undang No 23 Tahun 2002 tentang Perlindungan Anak, Pasal 81 menjelaskan setiap orang yang dengan sengaja melakukan kekerasan atau ancaman kekerasan memaksa anak melakukan persetubuhan dengannya atau dengan orang lain, dipidana dengan pidana penjara paling lama 15 (lima belas) tahun dan paling singkat 3 (tiga) tahun dan denda paling banyak Rp.300. 000. 000, 00 (tiga ratus juta rupiah) dan paling sedikit Rp. 60.000.000,00 (enam puluh juta rupiah).

Bertitik tolak dari Undang-udang tersebut, indikator tindakan pelecehan seksual berkaitan dengan ketidak inginan atau penolakan yang merugikan orang lain, karena dari perbuatan tersebut menyebabkan rasan tidak nyaman, marah, malu, menyinggung serta terintimidasi. Pelecehan seksual yang dimaksud dalam penelitian ini adalah tingkah laku individu melawan nilai kesopanan berkaitan dengan seksual menyangkut dengan verbal, visual dan fisik yang menimbulkan perasaan yang tidak nyaman, marah, malu, terintimidasi, dan menyinggung orang lain. Unsur penting dari pelecehan seksual adalah adanya ketidakinginan atau penolakan pada apapun bentuk-bentuk perhatian yang bersifat seksual. Apabila perbuatan tidak dikehendaki oleh si penerima perbuatan tersebut maka perbuatan itu bisa dikategorikan sebagai pelecehan seksual sebagaimana diatur dalam pasal percabulan. Kitab Undang-Undang Hukum Pidana (KUHP) secara umum (Lex Generalis) juga dapat dijadikan landasan dengan ancaman hukuman seperti yang diatur dalam Pasal pencabulan 289-299.

Tahap pelaksanaan Guru BK/Konselor Sekolah dalam tahap kegiatan, mengorganisasikan kegiatan layanan, mengaktifkan peserta didik, mengoptimalkan penggunaan metode dan media yang telah disediakan. Pelaksanaan kegiatan layanan informasi secara priodik sesuai kebutuhan siswa sekolah menengah atas kurang mendapat prioritas. Guru Pembimbin BK/Konselor Sekolah mengikuti program yang diprioritaskan sekolah bukan didasarkan oleh kebutuhan siswa. Tahap evaluasi, Guru $\mathrm{BK} /$ Konselor pada tahap evaluasi menetapkan materi evaluasi, prosedur evaluasi, menyusun instrument evaluasi, mengaplikasikan, mengolah, menetapkan norma atau standar evaluasi serta menafsirkan hasil analisis. Kegiatan tersebut dilakukan secara rutin sesuai dengan program yang telah ditetapkan sekolah. Evaluasi program dan kegiatan tidak dijadikan dasar perbaikan program berikutnya. Sedang tahap tindak lanjut, Guru BK/Konselor pada tahap tindak lanjut menetapkan jenis dan arah tindak lanjut, mengkomunikasikan kepada pihak terkait dan melaksanakan rencana tindak lanjut dalam upaya membantu peserta didik menyelesaikan permasalahannya. Permasalahan aturan serta kecenderungan tindakan pelecehan seksual yang dilakukan peserta didik kurang mendapat prioritas dari kegiatan layanan informasi. 
Setelah panduan layanan informasi untuk pencegahan tindakan pelecehan seksual selesai, dilanjutkan dengan validasi, uji praktikalitas, dan uji efektifitas panduan tersebut. Panduan yang telah dirancang dilanjutkan dengan kegiatan validasi oleh pakar dan praktisi sesuai dengan bidang kajian yang terdiri dari 6 orang validator. Enam Validator tersebut terdiri dari tiga orang validator pakar yang berasal dari perguruan tinggi dan tiga orang validator prktisi yang berasal dari Guru BK/Konselor Sekolah. Pakar dan praktisi diminta menilai panduan yang sudah dibuat. Penilaian mencakup isi, penyajian, kebahasaan, dan kegrafikan. Validator diminta untuk memberikan penilaian serta saran perbaikan terhadap panduan yang telah dirancang.

Berdasarkan hasil saran-saran dari validator dilakukanlah revisi terhadap buku panduan layanan informasi menggunakan pendekatan contextual teaching and learning dalam pencegahan kecenderungan tindakan pelecehan seksual siswa SMA Kota Padang. Setelah diidentifikasi saran-saran tersebut dapat dirumuskan seperti tabel berikut :

Tabel.4

Validasi Panduan Layanan Informasi dari Ahli

\begin{tabular}{|l|l|l|l|}
\hline No & Aspek Isi & $\begin{array}{l}\text { Tingkat } \\
\text { pencapaian }\end{array}$ & Kategori \\
\hline 1 & Materi Sesuai dengan Ruang Lingkup Layanan & 92 & $\begin{array}{l}\text { Sangat } \\
\text { valid }\end{array}$ \\
\hline 2 & $\begin{array}{l}\text { Materi Pelecehan Seksual dari segi verbal, visual } \\
\text { dan fisik beserta akibatnya di dikalangan remaja }\end{array}$ & 91 & $\begin{array}{l}\text { Sangat } \\
\text { valid }\end{array}$ \\
\hline 3 & $\begin{array}{l}\text { Aturan tentang Pelecehan Seksual dari segi } \\
\text { verbal, visual dan fisik beserta dampaknya } \\
\text { terhadap Pelanggaran }\end{array}$ & 91 & $\begin{array}{l}\text { Sangat } \\
\text { valid }\end{array}$ \\
\hline 4 & $\begin{array}{l}\text { Toleransi Antar jenis Kelamin dalam } \\
\text { mengimplementasikan aturan tentang pelecehan } \\
\text { seksual. }\end{array}$ & 91 & $\begin{array}{l}\text { Sangat } \\
\text { valid }\end{array}$ \\
\hline \multicolumn{2}{|c|}{ Rata-rata } & 91 & $\begin{array}{l}\text { Sangat } \\
\text { Valid }\end{array}$ \\
\hline
\end{tabular}

Berdasarkan Tabel di atas, aspek isi memperoleh nilai kisaran 88-92 rata-rata hasil $91 \%$ dengan ketegori Valid. Aspek isi dinilai sudah sesuai ruang lingkup kecenderungan pelecehan seksual, yaitu tingkah laku individu menyangkut verbal, visual dan fisik berkaitan dengan seksual yang menimbulkan perasaan yang tidak nyaman, marah, malu, terintimidasi, dan menyinggung orang lain.

Panduan layanan informasi menggunakan pendekatan Contextual Teaching and Learning untuk pencegahan kecenderungan tindakan pelecehan seksual yang sudah direvisi, diserahkan kembali kepada validator untuk didiskusikan lebih lanjut. Validator diminta memberikan penilaian dan pendapat terhadap panduan yang sudah direvisi. Validasi telah selesai apabila validator sudah menyatakan bahwa panduan yang dirancang sudah valid dan siap untuk diujicobakan.

\section{Praktikalitas Panduan Layanan Informasi untuk Pencegahan Tindakan Kekerasan}

Panduan pelaksanaan layanan informasi menggunakan pendekatan Contextual Teaching and Learning dinyatakan valid, selanjutnya dilakukan uji coba untuk mengetahui praktikalitas dan efektivitas panduan yang dikembangkan. Uji coba dilakukan kepada siswa SMA Adabiah selama tiga hari. Praktikalitas panduan yang dikembangkan dapat dilihat dari hasil 
pengamatan keterlaksanaan pembelajaran, angket pelecehan seksual, serta observasi penggunaan panduan.

Setelah angket pelecehan seksual diisi oleh siswa di awal dan akhir kegiatan, efektifitas penggunaan panduan layanan informasi menggunakan pendekatan Contextual Teaching and Learning untuk pencegahan kecenderungan pelecehan seksual, seperti tabel berikut :

Tabel 5

Hasil Pretest dan Posttest Kecenderungan Pelecehan Seksual Siswa Kelompok Eksperimen

\begin{tabular}{|c|c|c|c|c|c|c|}
\hline \multirow{2}{*}{ Responden } & \multicolumn{3}{|c|}{ Pretest } & \multicolumn{3}{|c|}{ Posttest } \\
\hline & Skor & $\%$ & Kategori & Skor & $\%$ & Kategori \\
\hline 1 & 175 & 81.4 & Tinggi & 163 & 75.8 & Sedang \\
\hline 2 & 171 & 79.5 & Tinggi & 166 & 77.2 & Tinggi \\
\hline 3 & 185 & 86 & SangatTinggi & 171 & 79.5 & Tinggi \\
\hline 4 & 176 & 81.9 & Tinggi & 165 & 76.7 & Tinggi \\
\hline 5 & 176 & 81.9 & Tinggi & 170 & 79.1 & Tinggi \\
\hline 6 & 178 & 82.8 & Tinggi & 165 & 76.7 & Tinggi \\
\hline 7 & 174 & 80.9 & Tinggi & 158 & 73.5 & Rendah \\
\hline 8 & 175 & 81.4 & Tinggi & 160 & 74.4 & Sedang \\
\hline 9 & 169 & 78.6 & Sedang & 155 & 72.1 & Rendah \\
\hline 10 & 182 & 84.7 & SangatTinggi & 168 & 78.1 & Tinggi \\
\hline 11 & 170 & 79.1 & Tinggi & 155 & 72.1 & Rendah \\
\hline 12 & 164 & 76.3 & Sedang & 161 & 74.9 & Rendah \\
\hline 13 & 167 & 77.7 & Sedang & 157 & 73 & Rendah \\
\hline 14 & 173 & 80.5 & Tinggi & 168 & 78.1 & Tinggi \\
\hline 15 & 174 & 80.9 & Tinggi & 170 & 79.1 & Tinggi \\
\hline 16 & 171 & 79.5 & Tinggi & 168 & 78.1 & Tinggi \\
\hline 17 & 171 & 79.5 & Tinggi & 155 & 72.1 & Rendah \\
\hline 18 & 167 & 77.7 & Sedang & 164 & 76.3 & Sedang \\
\hline 19 & 168 & 78.1 & Sedang & 158 & 73.5 & Rendah \\
\hline 20 & 167 & 77.7 & Sedang & 161 & 74.9 & Sedang \\
\hline 21 & 178 & 82.8 & Tinggi & 157 & 73 & Rendah \\
\hline 22 & 172 & 80 & Tinggi & 169 & 78.6 & Tinggi \\
\hline 23 & 170 & 79.1 & Tinggi & 164 & 76.3 & Sedang \\
\hline 24 & 173 & 80.5 & Tinggi & 166 & 77.2 & Tinggi \\
\hline 25 & 174 & 81 & Tinggi & 170 & 79.1 & Tinggi \\
\hline 26 & 177 & 82.3 & Tinggi & 170 & 79.1 & Tinggi \\
\hline
\end{tabular}




\begin{tabular}{|l|l|l|l|l|l|l|} 
Jumlah & 4497 & & & 4254 & & \\
\hline Rata-rata & 172.962 & 80 & Tinggi & 163.615 & 76.1 & Sedang \\
\hline Max & 185 & & & 171 & & \\
\hline Min & 164 & & & 155 & & \\
\hline
\end{tabular}

Berdasarkan tabel di atas, diperoleh informasi skor rata-rata hasil pretest siswa melakukan tindakan pelecehan seksual sebesar 172,962 dengan persentase $80 \%$, skor tertinggi 185 dan skor terendah 164. Bertitik tolak dari penyebaran data tersebut dapat ditafsirkan pelecehan seksual siswa berada pada kategori tinggi. Setelah dilakukan layanan informasi menggunakan contextual teaching and learning dilakukan posttest dengan skor rata-rata diperoleh 163,615 dengan persentase 76,1\%, skor tertinggi 171 dan skor terendah 155 . Sehubungan dengan hal itu, menunjukan kecenderungan pelecehan seksual siswa setelah mengikuti panduan layanan informasi menggunakan contextual teaching and learning layanan informasi berada pada kategori sedang. Dengan demikian dapat disimpulkan panduan layanan informasi menggunakan contextual teaching and learning dapat menurunkan tindakan pelecehan seksual siswa Sekolah Menengah Atas..

\section{Kesimpulan dan Saran}

Berdasarkan hasil penelitian dapat disimpulkan sebagai berikut remaja dari Sekolah Menengah Atas Kota padang memiliki kecenderungan tindakan pelecehan seksual berada pada kategori sedang, tinggi dan sangat tinggi. Kecenderungan pelecehan seksual remaja siswa SMA tersebut sebagian besar bersifat verbal dan visual. Panduan layanan informasi yang diperlukan remaja dari SMA dalam pencegahan tindakan pelecehan seksual, dimulai dari perencanaan, pelaksanaan, evaluasi dan tindak lanjut. Topik layanan informasi untuk pencegahan tindakan pelecehan seksual, menyangkut dengan : pelecehan seksual beserta dampak pelanggarannya, aturan tentang pelecehan seksual berserta akibatnya bagi pelanggar dan kemampuan bertoleransi dalam mengimplimentasikan aturan tentang pelecehan seksual antar jenis kelamin., yang penyusunan dimulai dari prencanaan, pelaksanaan, evaluasi dan tindak lanjut. Setelah dilakukan uji validitas, praktikalitas dan efektifitas menerangkan panduan layanan informasi untuk pencegahan tindakan pelecehan seksual valid, praktis dan efektif untuk digunakan dalam pelaksanaan layanan inforamsi di Sekolah Menengah Atas.

\section{DAFTAR RUJUKAN}

Ratih Probosiwi, D. B. (2015). Pedofilia dan Kekerasan Seksual: Masalah dan Perlindungan Terhadap Anak. Sosio Informa, 1(1), 29-40.

Sari, I. puspita. (2015). Kata Kunci: Pentingnya Pemahaman Kedudukan Dan Fungsi Bahasa Indonesia Sebagai Pemersatu Negara Kesatuan Republik Indonesia, 1(1), 234-242.

Yulita Amaliyasari, N. P. (2008). Perilaku Seksual Anak Usia Pra Remaja di Sekitar Lokalisasi dan Faktor yang Mempengaruhi. Jurnal Penelitian Dinas Sosial, 7(1), 54-60. Retrieved from http://journal.unair.ac.id/download-fullpapers-06 A-4 April 2008_54-60_.pdf

Akhyar Hasibuan. 2008. Efektifitas Layanan Bimbingan Kelompok dalam Meningkatkan Mutu Keterampilan Belajar. Tesis. tidak diterbitkan. Padang: Pasca Sarajana UNP.

Asri Budiningsih. 2008. Pembelajaran Moral. Jakarta: Rineka Cipta. 
Burhanuddin Salam. 2000. Etika Individual Pola Dasar Filsafat Moral. Jakarta: Rineka Cipta.

Buss, Ah. \& Perry, M. 1992. The Agression Questionare. Journal of Personality and Social Pscology. VolI: hal 1-7.

Citra Abriani Maharani. 2011. Efektifitas Pelaksanaan Bimbingan Kelompok dalam Meningkatkan Self-Esteem serta Aspirasi Karir. Tesis. tidak diterbitkan. Padang: Pasca Sarajana UNP.

Cipta.Santoso, Slamet. 2004. Dinamika Kelompok. Jakarta: Bumi Aksara.

Dewa Ketut Sukardi. 2000. Pengantar Pelaksanaan Program Bimbingan dan Konseling di Sekolah. Jakarta: Rineka Cipta.

Fadila, K. Firmandan Zikra. 2016. Efektifitas Layanan Bimbingan Kelompok Dalam Meningkatkan Pemahaman Siswa Terhadap Agresivitas. Skripsi. Tidak diterbitkan Padang: FIP UNP.

Firman, Zikra, Indah Sukmawati dan Rezki Hariko. 2014. Program Bimbingan dan Konseling dalam Penanggulangan Kekerasan dan Agresivitas Remaja Siswa SMTA Kota Padang. Padang: FIP UNP. Hafiz, Yusri dan Asmidir. 2013. Profil Siswa Agresif dan Peran Guru BK. Skripsi. Tidak diterbitkan. Padang: FIP UNP.

http://www.covesia.com/berita/24565/aksi-kekerasan-yang-dilakukan-seorang-pelajar-dipadang-terekam-kamera.html.

http://www.metrosiantar.com/2016/01/31/233442/video-penyiksaan-siswa-smk-beredar-kotapadang-heboh/.

http://m.minangkabaunews.com/artikel-7103-kasus-tawuran-pelajar-di-kota-padangmeningkat-didominasi-anak-smk.html.

Jim Bum. 2015. Teaching Your Children Healthy Sexuality. Diterjemahkan oleh Lenny Wati. (Cet. 11; t, t: Visipress, 2015). h. 110.

Maslihah, Sri. 2013. Play Therapy dalam Identifikasi Kasus Kekerasan Seksual terhadap Anak. Jurnal. (Bandung: Univeb dan Pendidikan Indonesia, 2013). h. 24.

Prayitno.1995. Layanan Bimbingan dan Konseling Kelompok Dasar dan Profil. Jakarta: Ghalia Indonesia.

Prayitno. 2004. Seri Layanan L6. Layanan Bimbingan Kelompok .Padang: Jurusan BK FIP UNP.

Prayitno \& Erman Amti. 2004.Dasar-dasar Bimbingan dan Konseling. Jakarta: Rineka. 
Prinsloo, Sakkie. 2006. Sexual Harassment and Violence in South African Schools. South African Journal of Education Vol. 26 (2) 305-318.

Sarlito, Wirawan. S. 2001. Psikologi Remaja. Jakarta: PT. Raja Grafindo Persada. Sarwono, S. W. dan Meinarno, E. A. 2009. Psikologi Sosial. Jakarta: Salemba Humanika.

Supardi, S \& Sadarjoen, Dampak Psikologis Pelecehan Seksual pada Anak Perempuan. http://www.kompas.com/kesehatan/news/0409/12/201621.htm. diakses 21 April 2017.

Sukardi, Dewa Ketut. 2000. Pengantar Pelaksanaan Program Bimbingan dan Konseling di Sekolah. Jakarta: Rineka Cipta.

Tylor, Shelley E., Peplau, Letitia Anne., Seas, David O. 2009. Psikologi Sosial Edisi Kedua belas. Alih Bahasa Tri Wibowo B. S. Jakarta:Kencana Media Group.

Verlanda Yuca, Firman dan Indah Sukmawati. 2012. Peningkatan Penyesuaian Diri Siswa melalui Layanan Bimbingan Kelompok. Skripsi. Tidak diterbitkan. Padang: FIP UNP. Wahid Sulaman. 2003. Teori dan Pratik Bimbingan Kelompok. Jakarta: Depdikbud. Winkel dan Sri Hastuti. 2004. Bimbingan dan Konseling di Insitusi Pendidikan (Edisi Revisi). Yoyakarta: Media Abadi.

Sugiarto. 2012. http://www.suaramerdeka.com/v1/index.php/read/news/2012/07/13/ 124082/Kenakalan-Remaja-di-Indonesia-Sudah-Sangat-Parah.Diakses pada tanggal 1 April 2016.

Admin.2012. https://metro.tempo.co/read/news/2012/09/27/064432335/setahun-17- pelajartewas-karena-tawuran.diakses pada tanggal 1 April 2016.

Afuanti, V., Widajati, S., \& Usnawati, N. 2010. Gambaran tingkat kecemasan ibu dalam masa klimakterium. Jurnal Penelitian Kesehatan Suara Forikes, 1(1), 58-63. Retrieved from http://static.schoolrack.com/files/100398/295411/volume1_nomor1.pdf

Rokhmah, D. 2016. Efektifitas Media Buku Pop-Up Sebagai Sarana Edukatif Anak Dalam Program "Protecting the Children From Sexual Predators", (June 2014).

Akhyar Hasibuan. 2008. Efektifitas Layanan Bimbingan Kelompok dalam Meningkatkan Mutu Keterampilan Belajar. Tesis. tidak diterbitkan. Padang: Pasca Sarajana UNP.

Asri Budiningsih. 2008. Pembelajaran Moral. Jakarta: Rineka Cipta.

Burhanuddin Salam. 2000. Etika Individual Pola Dasar Filsafat Moral. Jakarta: Rineka Cipta.

Buss, Ah. \& Perry, M. 1992. The Agression Questionare. Journal of Personality and Social Pscology. VolI: hal 1-7. 
Citra Abriani Maharani. 2011. Efektifitas Pelaksanaan Bimbingan Kelompok dalam Meningkatkan Self-Esteem serta Aspirasi Karir. Tesis. tidak diterbitkan. Padang: Pasca Sarajana UNP.

Cipta.Santoso, Slamet. 2004. Dinamika Kelompok. Jakarta: Bumi Aksara.

Dewa Ketut Sukardi. 2000. Pengantar Pelaksanaan Program Bimbingan dan Konseling di Sekolah. Jakarta: Rineka Cipta.

Fadila, K. Firmandan Zikra. 2016. Efektifitas Layanan Bimbingan Kelompok Dalam Meningkatkan Pemahaman Siswa Terhadap Agresivitas. Skripsi. Tidak diterbitkan Padang: FIP UNP.

Firman, Zikra, Indah Sukmawati dan Rezki Hariko. 2014. Program Bimbingan dan Konseling dalam Penanggulangan Kekerasan dan Agresivitas Remaja Siswa SMTA Kota Padang. Padang: FIP UNP.

Hafiz, Yusri dan Asmidir. 2013. Profil Siswa Agresif dan Peran Guru BK. Skripsi. Tidak diterbitkan. Padang: FIP UNP.

http://www.covesia.com/berita/24565/aksi-kekerasan-yang-dilakukan-seorang-pelajardi-padang-terekam-kamera.html.

http://www.metrosiantar.com/2016/01/31/233442/video-penyiksaan-siswa-smkberedar-kota-padang-heboh/.

http://m.minangkabaunews.com/artikel-7103-kasus-tawuran-pelajar-di-kota-padangmeningkat-didominasi-anak-smk.html.

Jim Bum. 2015. Teaching Your Children Healthy Sexuality. Diterjemahkan oleh Lenny Wati. (Cet. 11; t, t: Visipress, 2015). h. 110.

Maslihah, Sri. 2013. Play Therapy dalam Identifikasi Kasus Kekerasan Seksual terhadap Anak. Jurnal. (Bandung: Univeb dan Pendidikan Indonesia, 2013). h. 24.

Rokhmah, D. (2016). Efektifitas Media Buku Pop-Up Sebagai Sarana Edukatif Anak Dalam Program "Protecting the Children From Sexual Predators ", (June 2014).

Prayitno.1995. Layanan Bimbingan dan Konseling Kelompok Dasar dan Profil. Jakarta: Ghalia Indonesia.

Prayitno. 2004. Seri Layanan L6. Layanan Bimbingan Kelompok .Padang: Jurusan BK FIP UNP.

Prayitno \& Erman Amti. 2004.Dasar-dasar Bimbingan dan Konseling. Jakarta: Rineka.

Prinsloo, Sakkie. 2006. Sexual Harassment and Violence in South African Schools. South African Journal of Education Vol. 26 (2) 305-318. 
Sarlito, Wirawan. S. 2001. Psikologi Remaja. Jakarta: PT. Raja Grafindo Persada.

Sarwono, S. W. dan Meinarno, E. A. 2009. Psikologi Sosial. Jakarta: Salemba Humanika.

Supardi, S \& Sadarjoen, Dampak Psikologis Pelecehan Seksual pada Anak Perempuan. http://www.kompas.com/kesehatan/news/0409/12/201621.htm. diakses 21 April 2017.

Sukardi, Dewa Ketut. 2000. Pengantar Pelaksanaan Program Bimbingan dan Konseling di Sekolah. Jakarta: Rineka Cipta.

Tylor, Shelley E., Peplau, Letitia Anne., Seas, David O. 2009. Psikologi Sosial Edisi Kedua belas. Alih Bahasa Tri Wibowo B. S. Jakarta:Kencana Media Group.

Verlanda Yuca, Firman dan Indah Sukmawati. 2012. Peningkatan Penyesuaian Diri Siswa melalui Layanan Bimbingan Kelompok. Skripsi. Tidak diterbitkan. Padang: FIP UNP.

Wahid Sulaman. 2003. Teori dan Pratik Bimbingan Kelompok. Jakarta: Depdikbud.

Winkel dan Sri Hastuti. 2004. Bimbingan dan Konseling di Insitusi Pendidikan (Edisi Revisi). Yoyakarta: Media Abadi. 